\title{
Peningkatan Kemampuan Pemahaman Matematis Siswa Melalui Model Pembelajaran Think Pair Share
}

\author{
Eris Rismayanti ${ }^{*}$, Bana G Kartasasmita ${ }^{2}$, In In Supianti ${ }^{3}$ \\ 1,2,3Program Magister Pendidikan Matematika, Universitas Pasundan, Bandung, Indonesia; \\ ${ }^{1 *}$ erisrismayanti17@gmail.com; ${ }^{2}$ bana.kartasasmita@gmail.com; ${ }^{3}$ supianti@unpas.ac.id
}

Info Artikel: Dikirim: 16 Desember 2019; Direvisi: 7 Februari 2020; Diterima: 21 Februari 2020 Cara sitasi: Rismayanti, E., Kartasasmita, B. G., \& Supianti, I. I. (2020). Peningkatan Kemampuan Pemahaman Matematis Siswa Melalui Model Pembelajaran Think Pair Share. JNPM (Jurnal Nasional Pendidikan Matematika) 4(1), 154-167.

\begin{abstract}
Abstrak. Penelitian ini bertujuan untuk meningkatkan kemampuan pemahaman matematis siswa melalui penerapan model pembelajaran TPS (Think-Pair-Share) pada materi segiempat. Penelitian ini adalah penelitian tindakan kelas yang terdiri dari tiga siklus yang setiap siklusnya terdiri dari empat tahap, yaitu perencanaan, pelaksanaan, observasi, dan refleksi. Subjek penelitian ini adalah siswa kelas VII-8 SMP Negeri 18 Bandung yang berjumlah 33 orang. Teknik pengumpulan data meliputi wawancara, observasi, tes kemampuan pemahaman matematika, dan dokumentasi. Data yang terkumpul kemudian diolah dengan analisis deskriptif. Hasil penelitian menunjukan bahwa persentase ketuntasan kemampuan pemahaman matematika siswa pada siklus I berada pada kriteria sedang, pada siklus kedua mengalami peningkatan meskipun masih tetap pada kriteria sedang, dan pada siklus ketigapun mengalami peningkatan dengan kriteria tinggi. Sehingga penerapan model pembelajaran TPS (Think Pair Share) dapat meningkatkan kemampuan pemahaman matematika siswa.
\end{abstract}

Kata Kunci: Pemahaman Matematis, Penelitian Tindakan Kelas, Think Pair Share.

Abstract. This study aimed to improve the mathematical understanding ability of students through the application of Think-Pair-Share learning models on quadrilateral. This research was a class action research consisting of three cycles, each of which consists of four stages, namely planning, implementing, observing, and reflecting. The subjects of this study were students at class VII-8 Junior High School in Bandung, totaling 33 students. Data collection techniques included interviews, observation, mathematical understanding ability tests, and documentation. The collected data was then processed with descriptive analysis. The results of research on the application of the TPS learning model are as follows: the percentage of completeness of students' mathematical understanding ability in the first cycle was in the medium criteria, in the second cycle has increased although still remains in the medium criteria, and in the third cycle has also increased in high criteria. Based on the results of the study, it was concluded that the application of the TPS (Think Pair Share) learning model could improve the mathematical understanding ability of students.

Keywords: Mathematical Understanding, Action Research, Think Pair Share. 


\section{Pendahuluan}

Matematika merupakan mata pelajaran yang tingkat kesulitannya cenderung lebih tinggi dibandingkan dengan mata pelajaran lainnya, dengan tingkat struktur yang melampaui intuisi yang tidak terlatih (Varma \& Schwartz, 2011), sehingga banyak siswa yang ragu terhadap kemampuan dirinya dalam menyelesaikan soal-soal matematika, hal tersebut menyebabkan mereka tidak menyukai matematika, bahkan ada yang menghindarinya (Harkness \& Noblitt, 2017; Sinaga, 2018). Namun, matematika penting untuk dipelajari agar melatih siswa untuk berpikir logis, sistematis, dan reflektif, serta membiasakan siswa untuk ulet, tekun, dan teliti dalam menyelesaikan masalah. Herawati (2016) menyatakan bahwa matematika memiliki struktur dan keterkaitan yang kuat dan jelas antar konsepnya sehingga memungkinkan seseorang yang mempelajarinya terampil berpikir rasional, sistematis, logis, dan kreatif. Murdani, Johar, \& Turmudi (2013) menyatakan bahwa pembelajaran matematika di sekolah masih bersifat konvensional, sehingga siswa kurang bebas dalam mengekspresikan ide-ide yang mereka miliki. Bukan hanya di Indonesia, di Turkipun sama, pemahaman konsep tidak diajarkan secara intersif (Aydin, 2014).

Siswa lebih banyak menghafal konsep matematika yang diberikan guru dan menyelesaikan masalah secara prosedural, sehingga kemampuan pemahaman konsep matematisnya kurang terasah (Rizqi, 2019). Selain itu, Jening dan Dunne (Rahmawati, 2013) menyatakan bahwa masih banyak siswa yang mengalami kesulitan untuk mengaplikasikan matematika kedalam kehidupan sehari-hari, hal ini akan berdampak pada tingkat pemahaman siswa dalam mempelajari matematika. Pemahaman konsep menurut Plaxco \& Wawro (2015) merupakan tindakan menggambarkan kualitas esensial suatu konsep. Konsep matematika disini terdiri dari objek matematika dan hubungan antara mereka (Simon, Kara, Placa, \& Avitzur, 2018). Pemahaman formal matematika merupakan dasar untuk keberhasilan dalam belajar matematika (Hornburg, Rieber, \& McNeil, 2017). Menjelaskan dan memahami konsep matematika merupakan masalah yang kompleks dan menantang (Martin, 2008). Siswa dikatakan dapat memahami konsep suatu materi matematika apabila siswa dapat memecahkan masalah yang berhubungan dengan materi tersebut dengan menggunakan langkah yang benar (Octamela, Suweken, \& Ardana, 2019).

Kemampuan pemahaman matematis siswa di SMPN 18 Bandung masih perlu ditingkatkan, karena dilihat dari nilai ulangan matematika sebelumnya masih belum memenuhi kriteria ketuntasan minimal seperti pada Tabel 1 . 
Tabel 1. Nilai Ulangan Matematika

\begin{tabular}{lllllll}
\hline Hasil Belajar Siswa & KKM & $2016 / 2017$ & KKM & 2017/2018 & KKM & 2018/2019 \\
\hline Nilai Rata-rata & 70 & 58,76 & 65 & 55,18 & 65 & 50,02 \\
\hline
\end{tabular}

Untuk meningkatkan kemampuan pemahaman matematis siswa, guru dituntut untuk kreatif dan inovatif dalam menggunakan model pembelajaran yang sesuai dengan karakteristik materi dan siswa, agar siswa termotivasi untuk belajar matematika, karena pembelajaran yang efektif merupakan salah satu faktor yang paling penting untuk meningkatkan hasil belajar siswa (Orhun, 2012). Salah satu model pembelajaran yang memungkinkan untuk meningkatkan kemampuan pemahaman konsep matematis siswa adalah model pembelajaran Think Pair Share (TPS), karena dalam pembelajaran TPS siswa dituntut untuk: (1) think (berpikir), sehingga memungkinkan siswa untuk menggali kemampuan dirinya; (2) pair (berpasangan), sehingga melatih siswa untuk bekerja sama dengan orang lain; dan (3) share (berbagi), memberi kesempatan kepada siswa untuk menunjukkan partisipasi mereka kepada orang lain (Dharma, Pujiastuti, \& Harianja, 2019). Pada langkah think, siswa dilatih untuk dapat memahami suatu konsep yang sedang dipelajari sesuai dengan kemampuan masingmasing siswa. Pada langkah pair, siswa dapat mengkonfirmasi konsep yang mereka pahami dengan pasangannya. Dan pada langkah share mereka dilatih untuk dapat menyampaikan konsep yang mereka pahami kepada teman-teman yang lainnya menggunakan bahasanya sendiri.

Berdasarkan penelitian Dharma, Pujiastuti, \& Harianja (2019), dengan model TPS yang penelitiannya di SMA kelas $X$ dengan materi Sistem Persamaan, sedangkan peneliti mencoba menerapkan model TPS pada siswa kelas VII SMP dengan materi segiempat. Sehubungan dengan hal tersebut, penulis melakukan penelitian yang bertujuan untuk meningkatkan kemampuan pemahaman matematis siswa kelas VII SMPN 18 Bandung melalui penerapan model pembelajaran kooperatif tipe TPS. Selain itu, penelitian ini diharapkan dapat menjadi tambahan informasi bagi guru dan peneliti lain.

\section{Metode}

Metode penelitian ini adalah Penelitian Tindakan Kelas (PTK). Subyek penelitian ini adalah siswa kelas VII-8 SMP Negeri 18 Bandung yang berjumlah 33 orang. Penelitian dilaksanakan pada semester genap tahun pelajaran 2018-2019 yang berlangsung pada bulan April sampai Mei tahun 2019. Penelitian ini terdiri dari 3 siklus dengan masing-masing siklus membutuhkan 2 kali pertemuan. Setiap siklus terdiri dari 4 tahap menurut model Kemmis yaitu: (1) perencanaan (planning); (2) tindakan/pelaksanaan 
(acting); (3) pengamatan (observing); dan (4) refleksi (reflecting) (Sukardi, $\underline{2014})$.

Instrumen penelitian yang digunakan dalam penelitian ini adalah soal tes kemampuan pemahaman matematis berbentuk uraian sebanyak 6 soal. Sebelum diberikan, soal tes diujicobakan terlebih dahulu kepada 32 orang siswa kelas VIII. Hasilnya 4 soal valid dan 2 soal dilakukan revisi. Soal tes tesebut juga diuji reliabilitasnya, hasilnya soal tes realiabel dengan $r$ hitung 0,785 . Teknik analisis data yang digunakan adalah teknik deskriptif komparatif hasil tes kemampuan pemahaman matematis antar siklus. Indikator keberhasilan dalam penelitian ini adalah sebagai berikut: (1) kemampuan pemahaman matematis siswa pada materi segiempat meningkat dari pada setiap siklusnya; (2) Sekurang-kurangnya $70 \%$ siswa kelas VII SMPN 18 Bandung mencapai ketuntasan individu dengan Kriteria Ketuntasan Minimal (KKM) sebesar 65 pada materi segiempat.

\section{Hasil dan Pembahasan}

Data yang diperoleh dari penelitian ini adalah data proses pembelajaran yang dilakukan pada setiap siklus, data hasil pretes dan postes kemampuan pemahaman matematis. Kegiatan pembelajaran tiap siklus diuraikan sebagai berikut.

Kegiatan pada tahap perencanaan tindakan di siklus 1, 2, dan 3 adalah menyusun rancangan yang akan dilaksanakan, sesuai dengan temuan masalah dan gagasan awal dengan cara mengembangkan Rencana Pelaksanaan Pembelajaran (RPP), menyiapkan Lembar Kerja Siswa (LKS), menyusun dan menyiapkan lembar observasi, menyiapkan peralatan untuk mendokumentasikan kegiatan-kegiatan selama proses pembelajaran berlangsung dan mengadakan koordinasi dengan teman sejawat atau observer untuk membantu mengamati kegiatan PTK.

Siklus 1: Pada tahap ini guru melaksanakan desain pembelajaran dengan menggunakan model pembelajaran TPS. Dalam usaha ke arah perbaikan suatu perencanaan bersifat fleksibel dan siap dilakukan perubahan sesuai apa yang terjadi dalam proses pelaksanaan di lapangan. Pada siklus 1 dilakukan dua kali pertemuan, pertemuan pertama dan kedua membahas bangun datar persegi dan persegi panjang. Guru menyampaikan materi bentuk-bentuk bangun datar dan contohnya dengan media gambar, ketika menyajikan materi masih terdapat siswa yang ribut dan mengganggu temannya. 
Pada awal pembelajaran, guru menyampaikan tujuan dan motivasi pembelajaran kepada siswa. Guru membagikan LKS dan meminta siswa memikirkan penyelesaian jawaban dari LKS secara individu selama 15 menit (tahap think). Pada saat diberikan LKS sebagian siswa lebih memilih langsung mengerjakan tanpa membaca petunjuk pada kegiatan LKS terlebih dahulu sehingga siswa tidak dapat menyelesaikan LKS nya dengan baik dan benar. Guru membagi kelompok dan meminta siswa untuk duduk dalam kelompok yang telah ditentukan, pada tahap ini beberapa siswa tidak mau dikelompokkan dengan teman kelompok yang telah ditentukan namun guru memberikan pengertian bahwa inti dari kegiatan ini adalah kerjasama tim.

Guru meminta siswa untuk mendiskusikan jawaban secara berpasangan dalam kelompok (tahap pair). Pada tahap ini diharapkan siswa dapat lebih terlibat aktif dalam membantu sesamanya dalam memahami konsep (Shepherd \& Van de Sande, 2014). Diskusi merupakan pendekatan yang dapat meningkatkan keterlibatan kognitif dan motivasi siswa (Lachner, Weinhuber, \& Nückles, 2019). Ketika siswa berdiskusi dengan pasangannya masih banyak siswa yang bingung dalam mengerjakan LKS sehingga kelas menjadi ribut, guru berkeliling dan membimbing siswa dalam menyelesaikan LKS atau pada soal yang belum di pahami.

Setelah semua kelompok selesai berdiskusi, guru meminta kelompok untuk mempersentasikan hasil diskusinya di depan kelas, namun masih banyak siswa yang tidak berani mempersentasekan hasil diskusinya, pada tahap ini guru menunjuk beberapa kelompok yaitu kelompok 1, dan 2. Setelah siswa mempersentasikan hasil diskusinya, guru memberikan kesempatan kepada siswa lain untuk bertanya atau membandingkan jawaban yang sudah dipresentasikan temannya, ditahap ini siswa belum bisa mengkritik hasil kerja temannya, siswa memilih diam dan menerima jawaban dari kelompok penyaji. Selanjutnya guru mengevaluasi hasil kerja kelompok dan kegiatan individu selama berdiskusi. Berikut ini hasil jawaban siswa siklus 1 pada Gambar 1.

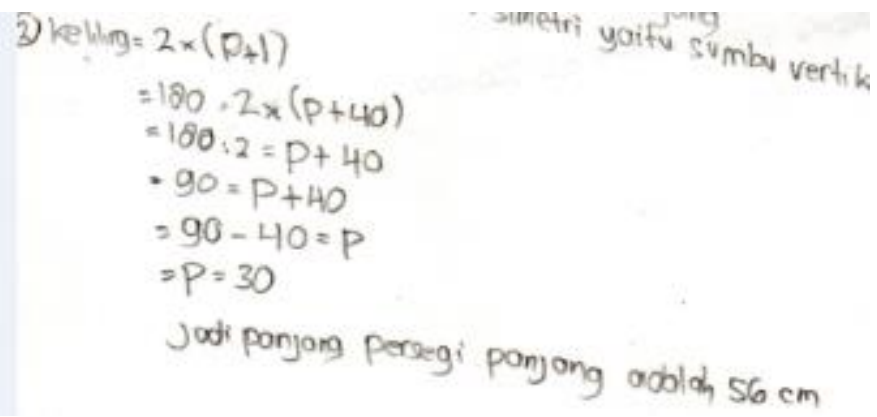

Gambar 1. Hasil Jawaban Siswa Siklus 1 
Berdasarkan hasil tersebut siswa belum bisa menerapkan aturan dalam perhitungan sederhana sesuai indikator kemampuan pemahaman matematis. Tetapi sudah bisa menerapkan rumus dalam perhitungan sederhana.

Siklus II: pada tahap ini guru melaksanakan desain pembelajaran dengan menggunakan model pembelajaran TPS. Langkah-langkahnya sama seperti pada siklus I. Siklus II dilakukan sebanyak dua kali pertemuan, yaitu pertemuan ketiga dan keempat yang membahas bangun datar jajar genjang dan belah ketupat.

Guru menyampaikan informasi materi tentang bentuk-bentuk bangun datar dan contohnya dengan media gambar, pada siklus kedua dalam menyajikan materi ada perubahan bahwa siswa mulai mengikuti pelajaran matematika dengan antusias. Pada awal pembelajaran sama seperti pada siklus I, Setelah semua kelompok selesai berdiskusi pada (tahap share) guru meminta kelompok untuk mempersentasikan hasil diskusinya ke depan kelas, siswa mulai berani mempersentasekan hasil diskusinya, pada tahap ini guru menunjuk beberapa kelompok yang belum tampil yaitu kelompok 3 dan 4 Setelah siswa mempersentasikan hasil diskusinya, guru memberikan kesempatan kepada siswa lain untuk bertanya atau membandingkan jawaban yang sudah dipresentasikan temannya, ditahap ini siswa sudah mulai bisa mengkritik hasil kerja temannya. Selanjutnya guru mengevaluasi hasil kerja kelompok dan kegiatan individu selama berdiskusi. Berikut ini contoh hasil jawaban siswa siklus 2 pada Gambar 2.

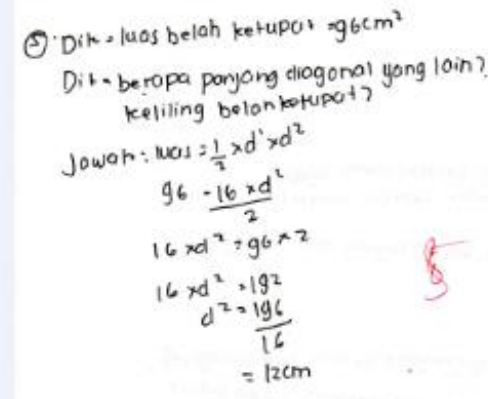

Gambar 2. Hasil Jawaban Siswa Siklus 2

Berdasarkan hasil jawaban siswa pada siklus 2 mulai ada pemahaman matematis bahwa siswa bisa menerapkan aturan dan rumus dalam perhitungan sederhana. 
Siklus III: Pada siklus III dilakukan dua kali pertemuan yaitu pertemuan kelima dan keenam dengan materi bangun datar layang-layang dan trapesium. Guru menyampaikan materi bentuk-bentuk bangun datar dan contohnya dengan media gambar, pada siklus ketiga dalam menyajikan materi ada perubahan yang lebih baik bahwa siswa mulai mengikuti pelajaran matematika dengan model pembelajaran TPS dengan antusias sekali. Langkah-langkah pembelajaran sama dengan siklus I dan II.

Pada siklus III siswa sudah mandiri dalam menyelesaikan LKS tanpa disuruh, pada tahap pair suasana mulai kondusif siswa mau bekerja sama dengan kelompoknya, dan tahap share siswa berani mempersentasikan hasil diskusinya, ditahap ini siswa sudah bisa mengkritik hasil kerja temannya. Selanjutnya guru mengevaluasi hasil kerja kelompok dan kegiatan individu selama berdiskusi. Berikut ini hasil jawaban siswa siklus 3 pada Gambar 3.

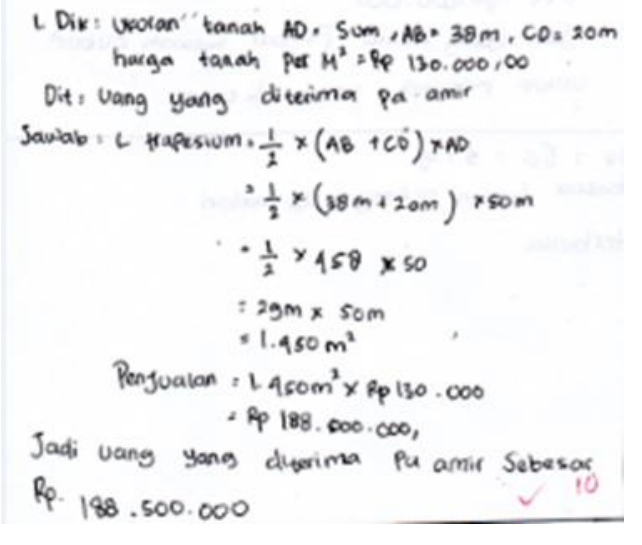

Gambar 3. Hasil Jawaban Siswa Siklus 3

Berdasarkan hasil jawaban siswa pada siklus 3 sudah tampak pemahaman matematisnya bahwa siswa mampu menerapkan aturan, rumus dalam perhitungan sederhana dan mengaitkan sesuatu dengan hal lainnya secara benar dan menyadari proses yang dilakukan.

Observasi yang dilakukan selama pembelajaran berlangsung (semua siklus) dilakukan sebagai upaya dalam mengamati pelaksanaan tindakan. Mengamati perilaku siswa terhadap kegiatan pembelajaran dan memantau kerja kelompok. Dalam melakukan observasi, peneliti dibantu observer yang turut mengamati jalannya pembelajaran berdasarkan lembar observasi keaktifan siswa yang telah disiapkan oleh peneliti.

Pada tahap refleksi peneliti berdiskusi dengan observer mengenai hasil pengamatan yang dilakukan selama pembelajaran. Refleksi bertujuan untuk 
mengetahui kekurangan dan kelebihan yang terjadi saat pembelajaran berlangsung. Hasil dari diskusi yang dilakukan akan digunakan sebagai bahan pertimbangan dalam merencanakan pembelajaran siklus berikutnya.

Pada siklus I, siswa secara keseluruhan menunjukkan keingintahuan masih kurang untuk memahami materi persegi dan persegi panjang dengan model pembelajaran TPS. Karena baru permulaan mereka masih terlihat malu-malu dan tidak berani untuk bertanya belum terbiasa dengan model pembelajaran TPS. Beberapa siswa mengajukan pertanyaan karena tidak memahami perintah pengerjaan. Pada kegiatan berkelompok, siswa tidak sabar untuk memulai kegiatan dan waktu dirasakan kurang. Penyebabnya siswa memerlukan waktu untuk menata meja dan kursi dalam formasi kelompok. walau ada beberapa siswa yang kelihatan masih belum berpartisipasi. Ketika kegiatan presentasi, siswa tampak masih malu-malu dan takut salah dalam menjawab pertanyaan-pertanyaan yang ada dalam LKS.

Kemudian untuk mengetahui hasil pembelajaran dan penekanan terhadap materi yang sudah dipelajarinya, siswa perlu diberi tugas mandiri secara individu. Pada siklus II direncanakan pembelajaran dengan memperhatikan hal-hal sebagai berikut: (a) peneliti harus mengingatkan kembali untuk belajar terlebih dahulu di rumah; (b) peneliti harus menyiapkan terlebih dahulu meja dan kursi untuk diskusi kelompok; (c) peneliti harus memfasilitasi siswa menemukan sendiri jawaban dalam soal LKS untuk kegiatan diskusi kelompok; (d) peneliti harus lebih memotivasi siswa untuk berani menyampaikan pendapatnya dalam kegiatan diskusi dan presentasi.

Pada siklus II, siswa hanya sebagian menunjukkan keingintahuan untuk memahami materi jajar genjang dan belah ketupat dengan model pembelajaran TPS. Beberapa siswa sudah tidak terlihat malu dan berani bertanya. Pada kegiatan berkelompok, siswa sudah mau bekerja sama dan berpartisipasi dengan temannya, meskipun baru sebagian. Kemudian untuk mengetahui hasil pembelajaran dan penekanan terhadap materi yang sudah dipelajarinya, siswa perlu diberi tugas mandiri secara individu untuk latihan di rumah dan mempelajari materi berikutnya.

Pada siklus III siswa secara keseluruhan menunjukkan keingintahuan yang besar untuk memahami materi layang-layang dan trapesium dengan model pembelajaran TPS. Hampir semua siswa sudah tidak terlihat malu dan mulai berani bertanya. Pada kegiatan berkelompok, siswa sudah bekerja sama dan berpartisipasi dengan baik bersama temannya. Kemudian siswa perlu diberi 
tugas individu untuk mengetahui hasil pembelajaran dan penekanan terhadap materi yang sudah dipelajarinya.

Kemudian untuk mengetahui hasil pembelajaran dan penekanan terhadap materi yang sudah dipelajarinya, siswa perlu diberi tugas mandiri secara individu. Observasi dilakukan oleh seorang observer setiap pertemuannya dimana aktivitaas guru adalah kesesuaian langkah-langkah di kelas dengan langkah-langkah model pembelajaran TPS. Hasil pengamatan akan dipresentase (\%) pada setiap pertemuan dan seluruh pertemuan. Hasil observer guru selama pembelajaran dengan menggunakan model pembelajaran TPS. Pada gambar 4 terlihat hasil rekapitulasi persentase aktivitas guru selama proses pembelajaran berlangsung sebanyak 6 kali pertemuan.

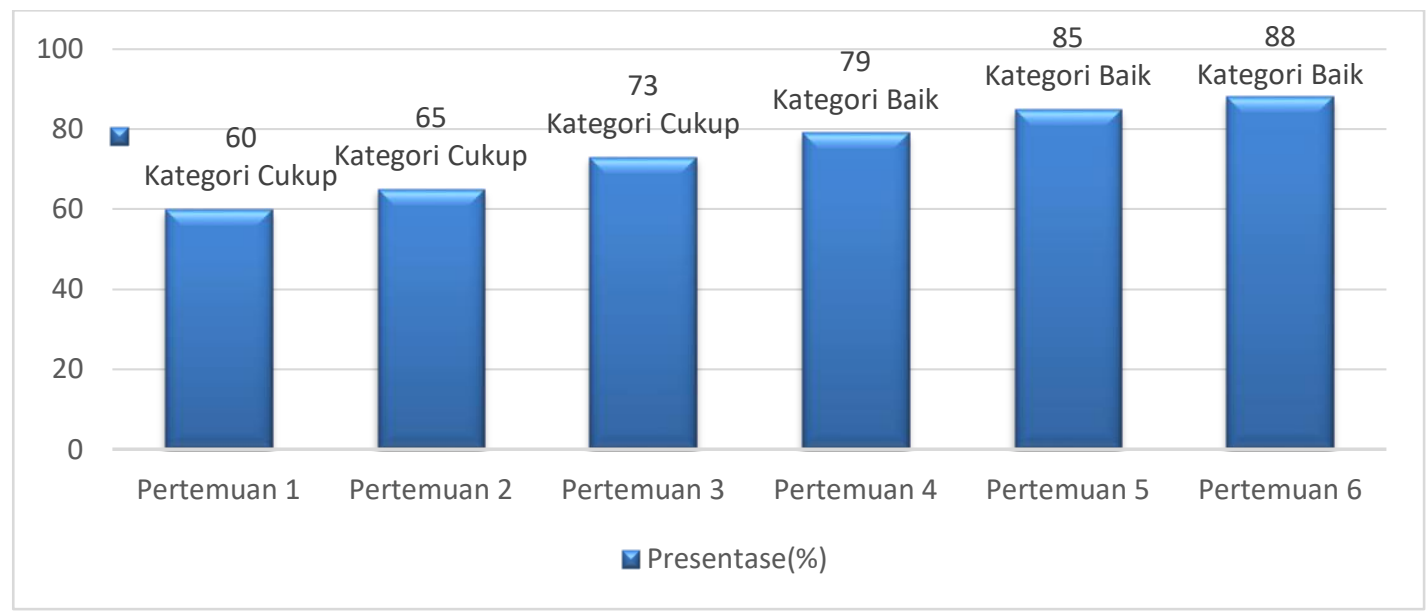

Gambar 4. Hasil Observasi Aktifitas Guru

Pada Gambar 4 memperlihatkan gambaran secara keseluruhan aktivitas guru yang dalam hal ini peneliti sendiri yang menerapkan hampir berjalan dengan baik. Pada pertemuan pertama sampai pertemuan ketiga persentase aktivitas guru dengan kategori cukup, sedangkan pertemuan keempat sampai pertemuan keenam persentase aktivitas guru pada kategori baik. Dari tabel terlihat bahwa aktifitas guru pada pertemuan pertama sampai pertemuan ketiga yaitu awal penelitian merupakan aktivitas yang rendah persentase sebesar $60 \%$, 65\%, dan $73 \%$ dibandingkan dengan pertemuanpertemuan yang lain. Hal ini disebabkan karena peneliti baru pertama menerapkan model pembelajaran TPS merasa kesulitan beradaptasi dengan situasi dan kondisi siswa, sedangkan untuk pertemuan selanjutnya sedikit mengalami peningkatan, karena guru sudah mulai terbiasa dengan lingkungan meskipun masih dikategorikan cukup dan begitu juga pada pertemuan selanjutnya yang semakin baik. Dapat disimpulkan bahwa 
aktivitas guru selama 6 kali pertemuan mengalami peningkatan dari pertemuan pertama sampai pertemuan keenam.

Observasi pada aktivitas siswa adalah sejauh mana respon yang diberikan siswa terhadap aktivitas yang dilakukan oleh siswa. Observasi dilakukan sebanyak enam kali pertemuan, observasi dilakukan mengamati penilaian aktivitas siswa selama proses pembelajaran dengan menggunakan model pembelajaran TPS. Observasi dilakukan kepada kelas eksperimen pada setiap pertemuan dapat dilihat pada Gambar 5 berikut.

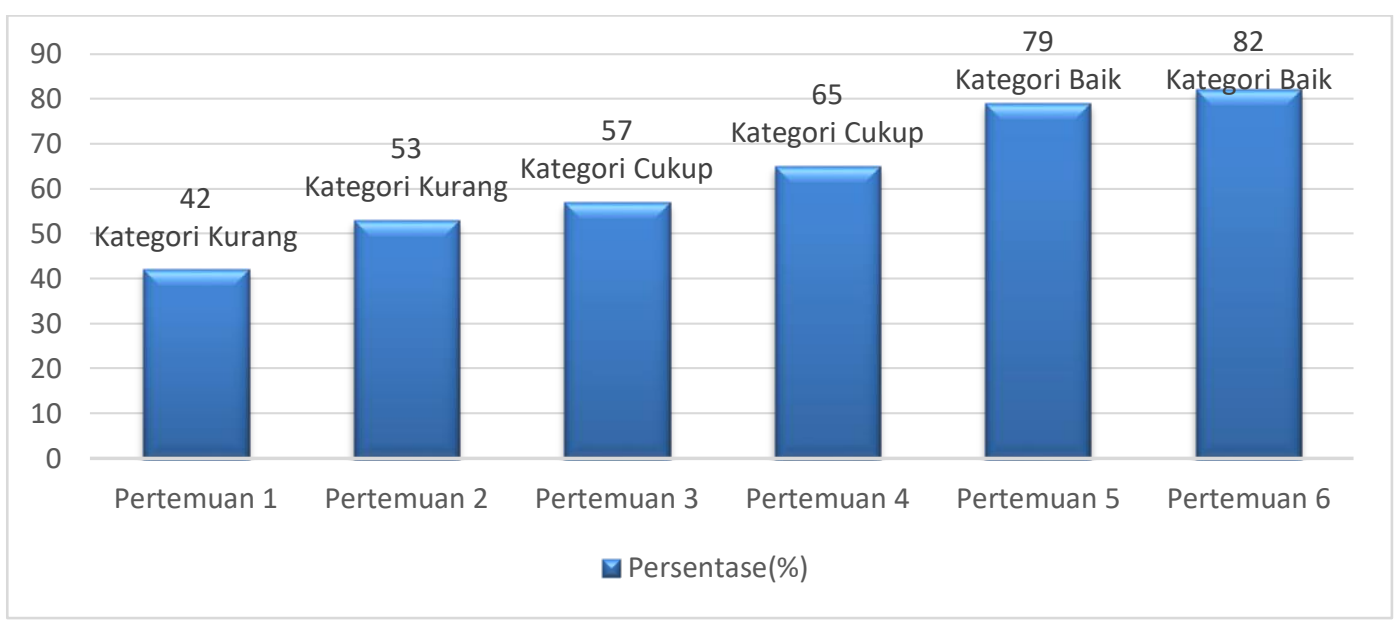

Gambar 5. Hasil Observasi Aktifitas Siswa

Berdasarkan Gambar 5 terlihat aktivitas siswa pada pembelajaran TPS di setiap pertemuan mengalami peningkatan yang tidak signifikan pada pertemuan pertama dan pertemuan kedua dengan kategori kurang. Begitu juga pertemuan ketiga dan keempat mengalami peningkatan yang tidak signifikan dengan kategori cukup. Tetapi pada pertemuan kelima dan keenam mengalami peningkatan dengan persentase $82 \%$ pada kategori baik. Berdasarkan Gambar 5 dapat disimpulkan bahwa aktivitas siswa selama 6 kali pertemuan mengalami peningkatan dengan rata-rata persentase $62 \%$ pada kategori cukup.

Data kemampuan pemahaman matematis pada pretes, diperoleh data bahwa dari 33 siswa kelas VII-8 SMPN 18 Bandung persentase banyaknya siswa yang nilai kemampuan pemahaman matematisnya belum memenuhi kriteria tercapai adalah $100 \%$ belum mencapai kriteria ketuntasan minimal 65 . Tidak hanya di Indonesia, di Amerikapun masih banyak siswa gagal dalam menguasai konsep yang diperlukan untuk menyelesaikan masalah yang kompleks (Reamer, Ivy, Vila-Parrish, \& Young, 2015). 


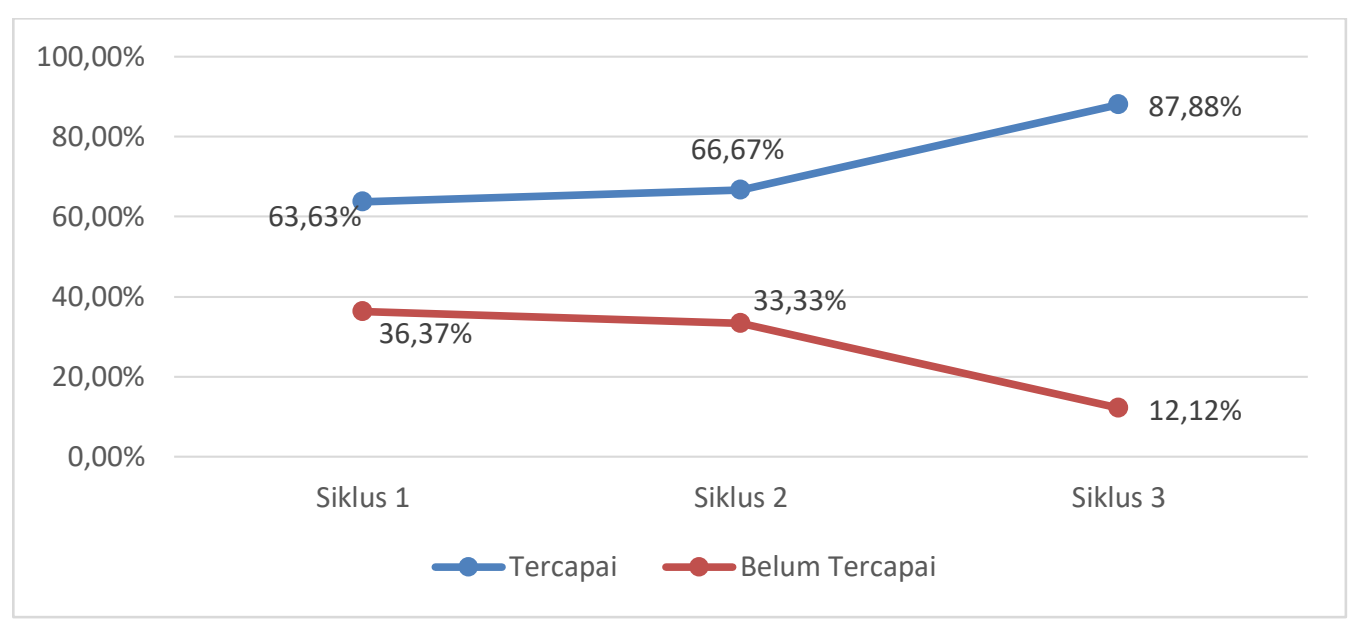

Gambar 6. Rekapitulasi Data kemampuan Pemahaman Matematis Siswa

Gambar 6 menunjukan adanya peningkatan rerata kemampuan pemahaman matematis siswa, meskipun peningkatan pada siklus I ke Siklus II tidak terlalu tinggi. Hal ini sejalan dengan hasil penelitian yang dilakukan oleh Lasmanah, (2016); Marta, (2017); Setyaningsih \& Rejeki, (2019) yang menyatakan bahwa model pembelajaran TPS dapat meningkatkan kemampuan pemahaman matematis siswa.

Pada siklus I, diperoleh data bahwa dari 33 siswa kelas VII-8 SMPN 18 Bandung, nilai kemampuan pemahaman matematis siswa tertinggi yang diperoleh adalah 90 dari nilai maksimum 100, sedangkan nilai yang terendah adala 30 dari nilai minimum 0 . Persentase banyak siswa yang nilai kemampuan pemahaman matematis berada pada kriteria tercapai (tuntas) sebesar $63,63 \%$ (21 orang), sedangkan persentase banyaknya siswa yang nilai kemampuan pemahaman matematisnya belum memenuhi kriteria tercapai (belum tuntas) adalah $36,36 \%$ (12 orang). Sementara itu, rata-rata nilai kemampuan pemahaman matematis siswa pada siklus I adalah 67,25 dengan kriteria sedang.

Pada siklus II, diperoleh data bahwa dari 33 siswa kelas VII-8 SMPN 18 Bandung, nilai kemampuan pemahaman matematis siswa tertinggi adalah 100 dari nilai maksimum 100, sedangkan nilai yang terendah adalah 50 dari nilai minimum 0 . Persentase banyaknya siswa yang nilai kemampuan pemahaman matematisnya belum memenuhi kriteria tercapai adalah 33,33\% (11 orang), sedangkan persentase banyaknya siswa yang skor kemampuan pemahaman matematisnya sudah memenuhi kriteria tercapai adalah $66,67 \%$ (22 orang). Sementara itu, rata-rata nilai kemampuan pemahaman matematis siswa pada siklus II adalah 69,07 dengan kriteria sedang. 
Pada siklus III, diperoleh data bahwa dari 33 siswa kelas VII-8 SMPN 18 Bandung, nilai kemampuan pemahaman matematis siswa tertinggi adalah 100 dari nilai maksimum 100, sedangkan nilai yang terendah adalah 60 dari nilai minimum 0. Persentase banyaknya siswa yang nilai kemampuan pemahaman matematisnya belum memenuhi kriteria tercapai adalah 12,12\% (4 orang), sedangkan persentase banyaknya siswa yang skor kemampuan pemahaman matematisnya sudah memenuhi kriteria tercapai adalah $87,87 \%$ (29 orang). Sementara itu, rata-rata nilai kemampuan pemahaman matematis siswa pada siklus III adalah 76,3 dengan kriteria tinggi.

Presentase peningkatan sebaran kemampuan pemahaman matematis siswa dari siklus I ke siklus II adalah 3,04\%, dari siklus II ke siklus III adalah 21,21 \%. Di lihat dari hasil siklus I, siklus II dan Siklus III terdapat peningkatan sehingga penerapan model TPS dapat meningkatkan kemampuan pemahaman matematis. Hal ini sejalan dengan penelitian Faqih (2019) bahwa pembelajaran dengan menggunakan pembelajaran TPS berpengaruh positif terhadap pemahaman konsep matematika. Karena terjadi peningkatan rata-rata nilai kemampuan pemahaman matematis siswa tiap siklusnya, maka dapat dinyatakan bahwa penelitian ini telah memenuhi indikitor keberhasilan yang telah ditentukan. Pengembangan pemahaman matematis berkorelasi dengan pengembangan rasa percaya diri siswa, terutama dalam menyelesaikan masalah matematika yang lebih kompleks (Romdiani \& Lestari, 2018).

\section{Simpulan}

Berdasarkan hasil penelitian dapat disimpulkan bahwa penerapan model pembelajaran Think Pair Share (TPS) dapat meningkatkan kemampuan pemahaman matematis siswa kelas VII-8 SMP Negeri 18 Bandung. Guru dapat menerapkan model ini untuk mengatasi rendahnya pemahaman matematis siswa.

\section{Ucapan Terima Kasih}

Terima kasih kepada kepala sekolah SMPN 18 Bandung yang telah memberi izin penelitian tindakan kelas, guru-guru dan siswa kelas VII-8 SMPN 18 Bandung yang telah berpartisipasi dalam penelitian ini. Ucapan terima kasih ini juga kami tujukan kepada semua pihak yang telah memberikan bantuan, dorongan, semangat serta bimbingan dalam penyelesaian artikel ini.

\section{Daftar Pustaka}

Aydin, Y. (2014). The Effects of Problem Based Approach on Student's Conceptual Understanding in a University Mathematics Classroom. Procedia - Social and Behavioral Sciences, 152, 704-707. 
Dharma, I., Pujiastuti, E., \& Harianja, M. (2019). Penerapan Model Pembelajaran TPS (ThinkPair-Share) untuk Meningkatkan Kemampuan Komunikasi Matematis dan Percaya Diri Peserta Didik Kelas X MIPA 1 SMA Negeri 6 Semarang Pada Materi Sistem Persamaan. PRISMA, Prosiding Seminar Nasional Matematika, 2, 239-246.

Faqih, A. (2019). Model Think Pair Share: Apakah Mempengaruhi Pemahaman Konsep Matematika? JNPM (Jurnal Nasional Pendidikan Matematika), 3(1), 40-50.

Harkness, S. S., \& Noblitt, B. (2017). Playing the believing game: Enhancing productive discourse and mathematical understanding. Journal of Mathematical Behavior, 45, 63-77.

Herawati, L. (2016). Pembelajaran melalui Strategi REACT untuk Meningkatkan Kemampuan Pemahaman Matematis Siswa Sekolah Menengah Kejuruan. Jurnal Penelitian Pendidikan Dan Pengajaran Matematika, 2(1), 35-40.

Hornburg, C. B., Rieber, M. L., \& McNeil, N. M. (2017). An Integrative Data Analysis of Gender Differences in Children's Understanding of Mathematical Equivalence. Journal of Experimental Child Psychology, 163, 140-150.

Lachner, A., Weinhuber, M., \& Nückles, M. (2019). To Teach or Not to Teach The Conceptual Structure of Mathematics? Teachers Undervalue The Potential of Principle-Oriented Explanations. Contemporary Educational Psychology, 58(March), 175-185.

Lasmanah, A. (2016). Peningkatan Hasil Belajar Matematika Siswa Melalui Model Kooperatif Teknik Think Pair Share (TPS) (Penelitian Tindakan Kelas Terhadap Siswa Kelas VII-A SMPN Sukasari Sumedang. Jurnal Analisa, 2(3), 18-26.

Marta, R. (2017). Peningkatan Hasil Belajar Matematika dengan Model Kooperatif Tipe Think Pair Share di Sekolah Dasar. Jurnal Cendekia : Jurnal Pendidikan Matematika, 1(2), 74-79.

Martin, L. C. (2008). Folding Back and The Dynamical Growth of Mathematical Understanding: Elaborating The Pirie-Kieren Theory. Journal of Mathematical Behavior, 27(1), 64-85.

Murdani, Johar, R., \& Turmudi. (2013). Pengembangan Perangkat Pembelajaran Matematika Dengan Pendekatan Realistik Untuk Meningkatkan Penalaran Geometri Spasial Siswa Di SMP Negeri Arun Lhokseumawe. Jurnal Peluang, 1(2), 22-32.

Octamela, K. S., Suweken, G., \& Ardana, I. M. (2019). Pemahaman Matematis Siswa Dengan Menggunakan Buku Elektronik Interaktif Berbantuan Geogebra. JNPM (Jurnal Nasional Pendidikan Matematika), 3(2), 305-315.

Orhun, N. (2012). Graphical Understanding in Mathematics Education: Derivative Functions and Students' Difficulties. Procedia - Social and Behavioral Sciences, 55, 679-684.

Plaxco, D., \& Wawro, M. (2015). Analyzing student understanding in linear algebra through mathematical activity. Journal of Mathematical Behavior, 38, 87-100.

Rahmawati, F. (2013). Pengaruh Pendekatan Pendidikan Realistik Matematika dalam Meningkatkan Kemampuan Komunikasi Matematis Siswa Sekolah Dasar. Prosiding SEMIRATA 2013, 1(1), 225-238.

Reamer, A. C., Ivy, J. S., Vila-Parrish, A. R., \& Young, R. E. (2015). Understanding the evolution of mathematics performance in primary education and the implications for STEM learning: A Markovian approach. Computers in Human Behavior, 47, 4-17.

Rizqi, M. (2019). Pengembangan Modul Dengan Pendekatan Pendidikan Matematika Realistik dalam Meningkatkan Kemampuan Pemahaman Matematis. PRISMA, Prosiding Seminar Nasional Matematika, 2, 330-336.

Romdiani, N. S., \& Lestari, P. (2018). Efektifitas Pembelajaran dengan Media Kartu Untuk Meningkatkan Kemampuan Pemahaman Matematis Siswa. JNPM (Jurnal Nasional Pendidikan Matematika), 2(2), 250-258.

Setyaningsih, R., \& Rejeki, S. (2019). Meningkatkan Prestasi Belajar Matematika Siswa Melalui Cooperative Learning Type Think Pair Share (TPS). DAYA MATEMATIS: 
Jurnal Inovasi Pendidikan Matematika, 7(2), 209-218.

Shepherd, M. D., \& Van de Sande, C. C. (2014). Reading Mathematics for UnderstandingFrom Novice to Expert. Journal of Mathematical Behavior, 35, 74-86.

Simon, M. A., Kara, M., Placa, N., \& Avitzur, A. (2018). Towards an Integrated Theory of Mathematics Conceptual Learning and Instructional Design: The Learning Through Activity Theoretical Framework. Journal of Mathematical Behavior, 52(1), 95-112.

Sinaga, N. (2018). Penerapan Pembelajaran Matematika Realistik untuk Meningkatkan

Kemampuan Pemahaman Matematis Siswa Pada Materi Bentuk Aljabar di Kelas VII SMP. Cartesius: Jurnal Pendidikan Matematika, 1(1), 25-35.

Sukardi. (2014). Metodologi Penelitian Pendidikan. Yogyakarta: Bumi Aksara.

Varma, S., \& Schwartz, D. L. (2011). The Mental Representation of Integers: An Abstract-ToConcrete Shift in The Understanding of Mathematical Concepts. Cognition, 121(3), 363385. 